\title{
Parasitoid diversity (Hymenoptera: Braconidae and Figitidae) on frugivorous larvae (Diptera: Tephritidae and Lonchaeidae) at Adolpho Ducke Forest Reserve, Central Amazon Region, Manaus, Brazil
}

\author{
Costa, SGM. ${ }^{\mathrm{a} *}$, Querino, RB. ${ }^{\mathrm{b} *}$, Ronchi-Teles, B. ${ }^{\mathrm{a} *}$,Penteado-Dias, AMM. ${ }^{\mathrm{c} *}$ and Zucchi, RA. ${ }^{\mathrm{d} *}$ \\ ${ }^{a}$ Coordenação de Pesquisas em Entomologia, \\ Instituto Nacional de Pesquisas da Amazônia - INPA,
}

Av. André Araújo, 2936, Petrópolis, CP 478, CEP 69011-970, Manaus, AM, Brazil

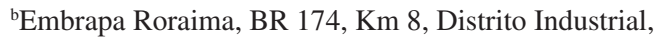
CEP 69301-970, Boa Vista, RR, Brazil

${ }^{c}$ Departamento de Ecologia e Biologia Evolutiva, Universidade Federal de São Carlos - UFSCar, CP 676, CEP 13565-905, São Carlos, SP, Brazil

'Escola Superior de Agricultura "Luiz de Queiroz" - ESALQ, Universidade de São Paulo - USP,

Av. Pádua Dias, 11, CEP 13418-900, Piracicaba, SP, Brazil

*e-mail: ronchi@inpa.gov.br, ranyse@cpafrr.embrapa.br,

angelica@power.ufscar.br, razucchi@esalq.usp.br

Received June 25, 2007 - Accepted November 29, 2007 - Distributed May 31, 2009

(With 2 figures)

\begin{abstract}
This study aimed to identify parasitoid species of frugivorous larvae and to describe the tritrophic interactions involving wild fruits, frugivorous insects and their natural enemies at Adolpho Ducke Forest Reserve (RFAD) (Manaus, AM, Brazil). Collections were performed in four $1 \mathrm{~km}^{2}$ quadrants in the corners of the RFAD. The wild fruits were collected inside the forest in access trails leading to each collection area and in trails that surrounded the quadrants, up to five metres from the trail on each side. The fruits were placed in plastic containers covered with thin fabric, with a vermiculite layer on the base to allow the emergence of flies or parasitoids. Seven Braconidae species were collected, distributed among Opiinae: Doryctobracon areolatus (Szépligeti, 1911), Utetes anastrephae (Viereck, 1913), and Opius sp., and Alysiinae: Asobara anastrephae (Muesebeck, 1958), Phaenocarpa pericarpa Wharton and Carrejo, 1999, Idiasta delicata Papp, 1969, and Asobara sp. Parasitism rates by braconids and figitids are presented. Doryctobracon areolatus was the most frequent, parasitizing the highest number of fly species, and showing the highest parasitism percentage in larvae feeding on Micropholis williamii fruits. The collected figitids belong to Aganaspis nordlanderi Wharton, 1998 and A. pelleranoi (Brethes, 1924). All 15 tritrophic associations are new records for the Brazilian Amazon region. The RFAD is an important natural reservoir of frugivorous larvae parasitoids.
\end{abstract}

Keywords: fruit fly, parasitoids, forest reserve, native fruit, Amazon.

\author{
Diversidade de Parasitóides (Hymenoptera: Braconidae e Figitidae) \\ de larvas frugívoras (Diptera: Tephritidae e Lonchaeidae) na \\ Reserva Florestal Adolpho Ducke, Amazônia Ocidental, Manaus, Brasil
}

\section{Resumo}

Este trabalho teve por objetivo identificar as espécies de parasitóides de larvas frugívoras e descrever as interações tritróficas desses inimigos naturais com seus insetos hospedeiros e frutos silvestres da Reserva Florestal Adolpho Ducke (RFAD). As coletas foram realizadas em quatro quadrantes de $1 \mathrm{~km}^{2}$, ocupando áreas próximas aos cantos da RFAD. Os frutos silvestres foram coletados no interior da floresta nas trilhas de acesso a cada área de coleta e nas trilhas que delimitavam os quadrantes, até cinco metros em cada lado. Os frutos foram acondicionados em recipientes plásticos, cobertos com tecido fino, contendo camada de vermiculita, para obtenção das moscas ou dos parasitóides, que eram individualizados, contados, sexados e fixados em álcool 70\%. As taxas de parasitismo por braconídeos e figitídeos são apresentadas. Foram coletadas sete espécies de Braconidae, distribuídas em Opiinae: Doryctobracon areolatus (Szépligeti, 1911), Utetes anastrephae (Viereck, 1913), Opius sp. e Alysiinae: Asobara anastrephae (Muesebeck, 1958), Phaenocarpa pericarpa Wharton e Carrejo, 1999, Idiasta delicata Papp, 1969 e Asobara sp. Doryctobracon 
areolatus foi a espécie mais frequente, parasitando o maior número de espécies de moscas e apresentando a maior percentagem de parasitismo em larvas em frutos de Micropholis williamii. OS figitídeos pertenciam a Aganaspis nordlanderi Wharton, 1998 e A. pelleranoi (Brethes, 1924). Todas as 15 associações tritróficas obtidas representam novos registros para a região Amazônica brasileira.

Palavras-chave: moscas-das-frutas, parasitóides, reserva florestal, frutos nativos, Amazônia.

\section{Introduction}

The deforestation rate in the Amazon Region has been on the rise in recent years, due to the actions of sawmills and the inappropriate use of forest resources by the local population (Fearnside, 2003). Among other implications, deforestation affects the environment and causes biodiversity losses by habitat fragmentations (Myers, 1992), which have a greater impact on parasitoids than on insect hosts (Krues and Tscharntke, 2000). It is estimated that $75 \%$ of the insect species in the Brazilian Amazon Rainforest are still unknown, and many species disappear before even being described (J. A. Rafael, pers. info.).

The rapid deforestation of the tropics may cause the extinction of many fruit fly species and consequently of their parasitoids (Aluja et al., 2003). The diversity of fruit hosts of tephritids is relatively high in the Neotropical region; however, there is a lack of biological information on most fruit fly species, as well as on their parasitoids, especially those associated with fruit fly species without significant economic importance (Ovruski et al., 2000).

The necessary information for understanding fruit fly biology, ecology, and evolution must be researched in nearly-unchanged native vegetation areas (Aluja et al., 2003). Studies in these areas are essential for obtaining knowledge of the tritrophic interactions among parasitoids, insect hosts, and associated plants.

In the Brazilian Amazon region, fruit flies have been studied in domestic orchards and agroforestry plantations; however, information on wild fruits is scarce. The availability of host fruits, in addition to the great biodiversity of the Amazon ecosystem, make fruit plants potential infestation sites, since they produce fruits throughout the year (Silva and Ronchi-Teles, 2000).

Twelve plant families have been identified whose fruits are hosts of fruit flies in the State of Amazonas (Silva et al., 1996). Many are still found in their wild state, such as mapati (Moraceae: Pourouma cecropiaefolia), camucamu (Myrtaceae: Myrciaria dubia), mari (Icacinaceae: Poraqueiba paraensis), bacuri (Clusiaceae: Rheedia brasiliensis), ice-cream bean (Mimosaceae: Inga edulis), bell-apple (Passifloraceae: Passiflora nitida), and guavade-anta (Melastomataceae: Bellucia grossularioides) (Silva and Ronchi-Teles, 2000).

Recent research conducted in Mexico and Brazil has shown that the hymenopteran guild of native parasitoids with potential for biological control has been inadequately evaluated because of the emphasis placed on exotic parasitoids (Ovruski et al., 2000). Among native parasitoids, Doryctobracon areolatus is the most generalist and most frequently collected in surveys conducted in several Brazilian localities, including those of the Amazon region (Silva, 1993; Canal-Daza, 1993, Ronchi-Teles, 2000; Creão, 2003; Tregue-Costa, 2004). The predominance of $D$. areolatus is related to its effectiveness in locating fruit fly host plants, and to its long ovipositor and capacity to parasitize larvae at their initial stages of development (Matrangolo et al., 1998).

The present study aims to identify parasitoid species of frugivorous larvae and describe the tritrophic interactions of these insects with wild fruits at the Adolpho Ducke reserve.

\section{Material and Methods}

The study was conducted at Adolpho Ducke Forest Reserve (RFAD), Instituto Nacional de Pesquisas da Amazônia (INPA), located on the AM 010 road, Km 26, northeast of the city of Manaus ( $02^{\circ} 53^{\prime} \mathrm{S}$ and $\left.59^{\circ} 59^{\prime} \mathrm{W}\right)$ (Figure 1a). Despite its proximity to Manaus, the reserve is still almost undisturbed, covered by typical dryland evergreen tropical forest. RFAD has an area of $100 \mathrm{~km}^{2}$, with a trail network that completely covers the reserve. The mean annual temperature is $26.5^{\circ} \mathrm{C}$, with a monthly mean maximum of $38.6^{\circ} \mathrm{C}$ (December) and minimum of $18.2{ }^{\circ} \mathrm{C}$ (July). The mean annual relative humidity is $82 \%$ (Araújo, 1970). The rainy period extends from November to May, with a perceptible decrease in the other months, markedly in the months of August and September (Marques Filho et al., 1981).

Collections were performed in four $1 \mathrm{~km}^{2}$ quadrants (Figure 1b). The wild fruits were collected inside the forest on access trails to each collection area and on trails that delimited the quadrants, up to five metres on each side. The mean time required to walk through to each collection area was six hours. Fruits were collected on the ground and/or still hanging from trees and placed in plastic containers to be transported to the laboratory, where the fruits were properly identified and recorded, placed in plastic containers containing a $3.0 \mathrm{~cm}$ layer of vermiculite, the containers covered by thin fabric (organza) and maintained at room conditions (mean temperature of $26^{\circ} \mathrm{C}$ and $\mathrm{RH} 80 \%$ ) in the rearing laboratory. After one week, the vermiculite was sifted (1.5 mm mesh) every five days to separate the puparia, which were maintained 

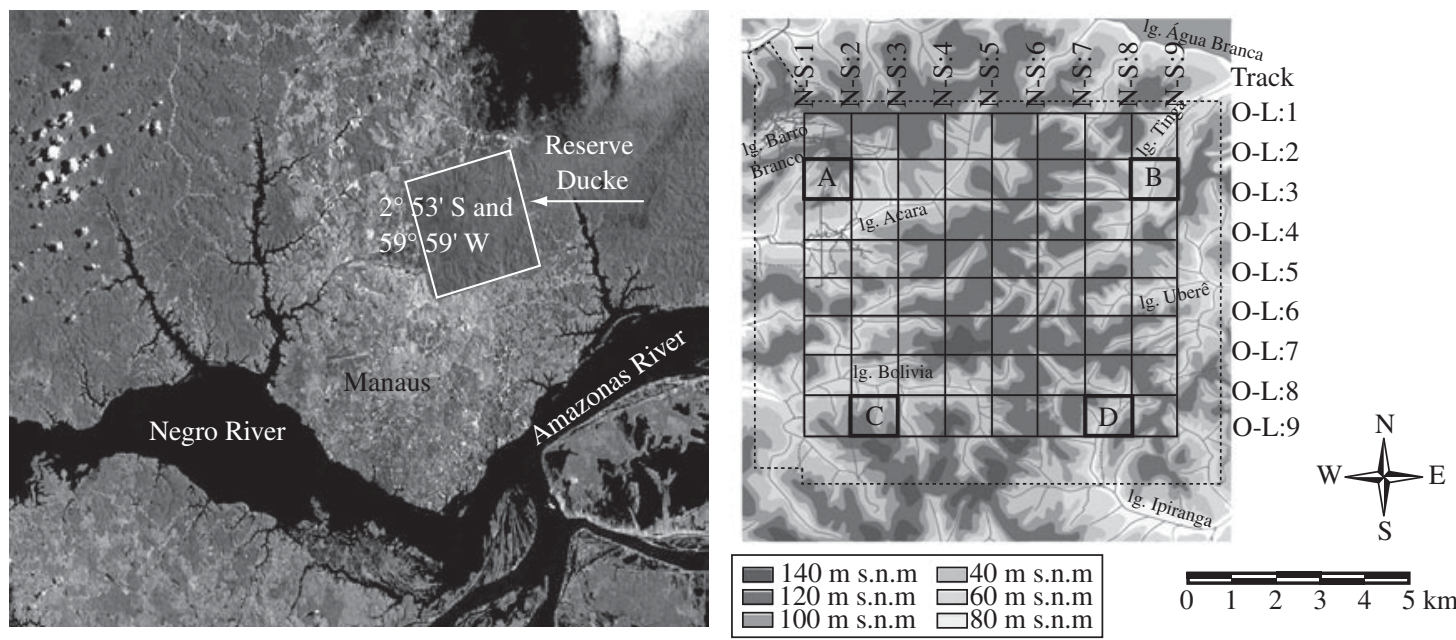

Figure 1. a) Satellite image of the city of Manaus . Detail: Adolpho Ducke Forest Reserve (Source: Inpe 1999); and b) Schematic representation of the reserve topography, indicating four collection areas. A - Acará micro-watershed, B - Tinga micro-watershed, C - Bolivia micro-watershed, D - Ipiranga micro-watershed (adapted from Ribeiro et al., 1999).

in plastic containers with a fine layer of vermiculite to obtain flies or parasitoids. Those were individualized, counted, sexed, and fixed in 70\% alcohol. An association between a fly species and a parasitoid species was considered to exist when a single fly species and a single parasitoid species emerged from a given container (Leonel Jr. et al., 1996).

Parasitism percentage calculations were based on Hernández-Ortiz et al. (1994): \% parasitism = number of parasitoids emerged/number of puparia obtained x 100 .

Braconid identifications were based on Wharton et al. (1997) and Canal-Daza and Zucchi (2000), while figitids were identified based on Guimarães et al. (2003). Plant species were identified using the Ribeiro et al. (1999) guide and, when needed, compared with specimens at the INPA herbarium. The fly and parasitoid voucher specimens are deposited in INPA's Invertebrate Collection.

\section{Results}

One hundred and eighty-five hymenopteran parasitoid specimens of frugivorous larvae were collected at Adolpho Ducke Forest Reserve (69\% Braconidae and $31 \%$ Figitidae). The braconids belonged to three species of Opiinae (87\%): Doryctobracon areolatus (Szépligeti), Utetes anastrephae (Viereck), and Opius sp., and four species of Alysiinae (13\%): Asobara anastrephae (Muesebeck), Phaenocarpa pericarpa Wharton and Carrejo, 1999, Idiasta delicata Papp, 1969, and Asobara sp. (Table 1)

Braconidae (Opiinae). As observed in other localities of Brazil (e.g. Canal-Daza and Zucchi, 2000), D. areolatus was the most frequent species and parasitized the greatest number of fly species in the reserve: Anastrepha coronilli Carrero and Gonzales, A. bahiensis
Lima, A. fractura Stone, and three possibly new species of Anastrepha (Anastrepha sp.2, Anastrepha sp.7, Anastrepha sp.8) (Tephritidae) and two species of Neosilba currently under description (Neosilba sp.1 and Neosilba sp.6) (Lonchaeidae). Opius sp. occurred in relatively small numbers. A reduced number of this parasitoid had also been observed in the northwestern part of the reserve (Tregue-Costa, 2004). However, in some State of Amazonas countries, Opius sp. is as abundant as D. areolatus and Opius bellus Gahan, 1930 and, in other localities, this species is predominant in rural areas while D. areolatus is predominant in urbanized areas (Silva, 1993; Canal-Daza, 1993). There have been questions on whether Opius sp. is a new species or an intraspecific variation of Opius bellus; nevertheless, molecular studies are underway to clarify the identity of these specimens. Utetes anastrephae is recorded for the first time parasitizing A. bahiensis Lima, 1937 (Table 1); however, it had been previously recorded in larvae of A. obliqua (Macquart, 1835) and of A. manihoti Lima, 1934, in the State of Amazonas (Canal-Daza, 1993)

Braconidae (Alysiinae). Asobara anastrephae was the most frequent among the alysiines (6\% over the total). This is the first record of A. anastrephae parasitizing A. bahiensis (Table 1). Phaenocarpa pericarpa is recorded for the first time in the Amazon region and also associated for the first time with Neosilba species (Table 1). The previous record of a species of Phaenocarpa in the State of Amazonas represents in fact an identification error of a species of Asobara (see Canal-Daza, 1993). Phaenocarpa pericarpa had only been previously associated with A. distincta Greene, 1934 in Venezuela (Trostle et al., 1999). Idiasta delicata is reported for the first time parasitizing frugivorous larvae in Brazil. It was reared from larvae on Duckeodendro cestroides fruits; however, it could not be associated with the host species because 
Table 1. Hymenopteran parasitoids of frugivorous larvae in wild fruits at Adolpho Ducke Forest Reserve, Manaus, Amazonas, Brazil. January to July 2004.

\begin{tabular}{|c|c|c|}
\hline Parasitoids & Number of specimens & Hosts (Tephritoidea) \\
\hline \multicolumn{3}{|l|}{ Braconidae: Opiinae } \\
\hline Doryctobracon areolatus & 8 & Anastrepha fractura \\
\hline Doryctobracon areolatus & 1 & Anastrepha sp.2 \\
\hline Doryctobracon areolatus & 1 & Anastrepha sp.7 and Anastrepha sp.8 \\
\hline Doryctobracon areolatus & 22 & Anastrepha bahiensis \\
\hline Doryctobracon areolatus & 1 & Anastrepha coronilli \\
\hline Doryctobracon areolatus & 23 & Anastrepha sp.* \\
\hline Doryctobracon areolatus & 2 & Neosilba sp.1 \\
\hline Doryctobracon areolatus & 2 & Neosilba sp.6 \\
\hline Doryctobracon areolatus & 30 & no association with a host \\
\hline Utetes anastrephae & 2 & Anastrepha bahiensis \\
\hline Utetes anastrephae & 9 & no association with a host \\
\hline Opius sp. & 10 & no association with a host \\
\hline \multicolumn{3}{|l|}{ Braconidae: Alysiinae } \\
\hline Asobara anastrephae & 7 & Anastrepha bahiensis \\
\hline Asobara anastrephae & 1 & no association with a host \\
\hline Phaenocarpa pericarpa & 1 & Neosilba sp.5 e Neosilba sp.1 \\
\hline Phaenocarpa pericarpa & 4 & no association with a host \\
\hline Idiasta delicata & 2 & no association with a host \\
\hline \multicolumn{3}{|l|}{ Figitidae: Eucoilinae } \\
\hline Aganaspis nordlanderi & 2 & Anastrepha sp.4 \\
\hline Aganaspis nordlanderi & 6 & Anastrepha fractura \\
\hline Aganaspis nordlanderi & 23 & no association with a host \\
\hline Aganaspis nordlanderi & 1 & Neosilba sp.1 \\
\hline Aganaspis pelleranoi & 3 & Anastrepha fractura \\
\hline Aganaspis pelleranoi & 19 & no association with a host \\
\hline
\end{tabular}

* Male Anastrepha specimen.

both tephritids and lonchaeids emerged from the same rearing container. Previously, only a record has existed for an unidentified Idiasta species parasitizing a frugivorous larva in Venezuela (Ovruski et al., 2000).

Figitidae. Aganaspis nordlanderi Wharton, 1998 emerged from $A$. fractura puparia (first record) and from other host species not yet described (Anastrepha sp.4 and Neosilba sp.1). Aganaspis pelleranoi (Brethes, 1924) parasitized only A. fractura (first record) (Table 1).

\subsection{Parasitism of frugivorous larvae}

The general parasitism percentage on frugivorous larvae was extremely variable in the reserve: $66.67 \%$ in fruits of Micropholis williamii and $0.93 \%$ on Duckeodendron cestroides (Table 2). In four State of Amazonas countries, parasitism values also varied considerably (0.03 to $23.41 \%$ ) (Canal-Daza, 1993). Great variations in parasitism percentages were also observed in reserves in Mexico (Hernández-Ortiz et al.,1994; Aluja et al., 2003). These variations, in addition to intrinsic host fruit traits (Sivinski, 1991), are also a result of peculiarities of each region (Sivinski et al., 2000).

Doryctobracon areolatus had the highest parasitism percentage $(66.7 \%)$ on larvae in $M$. williamii fruits (Table 3), while in other opiines parasitism rates were: Opius sp. (1.63 to $3.10 \%$ ) and U. anastrephae (4.97\%) on A. edentula. In other localities in the State of Amazonas, Opius sp. has shown higher parasitism percentages, but with quite variable values $(0.04 \%)$ on Mangifera indica (mango) and $33.3 \%$ on Platonia insignis (bacuri) (Canal-Daza, 1993). Among the Alysiinae, the highest parasitism percentage occurred with $P$. pericarpa on Eschweilera atropetiolata (Table 3).

The highest parasitism percentage by figitids was observed for A. pelleranoi (20\%) on O. platyspermum fruits. These are the first data on parasitism percentages of eucoilines in the State of Amazonas (Table 3). 
Table 2. Total parasitism percentage of frugivorous larvae in wild fruits at Adolpho Ducke Forest Reserve, Manaus, Amazonas, Brazil. January to July 2004.

\begin{tabular}{llccc}
\hline \multicolumn{1}{c}{ Families } & \multicolumn{1}{c}{ Species } & $\begin{array}{c}\text { Number of } \\
\text { puparia }\end{array}$ & $\begin{array}{c}\text { Number of } \\
\text { parasitoids }\end{array}$ & Parasitism (\%) \\
\cline { 1 - 2 } Annonaceae & Guatteria discolor & 82 & 2 & 2.44 \\
Duckeodendraceae & Duckeodendro cestroides & 216 & 2 & 0.93 \\
Lecythidaceae & Eschweilera atropetiolata & 44 & 7 & 15.91 \\
Leguminosae:Papilionoideae & Dipterix odorata & 61 & 3 & 4.92 \\
Melastomataceae & Bellucia dicotoma & 17 & 1 & 5.88 \\
Moraceae & Maquira esclerofila & 306 & 66 & 21.57 \\
Sapotaceae & Micropholis williamii & 3 & 2 & 66.67 \\
Siparunaceae & Siparuna guianensis & 56 & 3 & 5.36 \\
Ulmaceae & Ampelocera edentula & 161 & 83 & 51.55 \\
\hline
\end{tabular}

Table 3. Parasitism percentage of parasitoids in frugivorous larvae in wild fruits at Adolpho Ducke Forest Reserve, Manaus, Amazonas, Brazil. January to July 2004.

\begin{tabular}{|c|c|c|c|c|c|c|c|c|}
\hline \multirow[t]{2}{*}{ Native plant species } & \multicolumn{6}{|c|}{ Braconidae $^{1}$} & \multicolumn{2}{|c|}{ Figitidae $^{2}$} \\
\hline & Da & $\mathbf{O}$ & Ua & Aa & $\mathbf{P p}$ & Id & An & Ap \\
\hline Guatteria discolor & 2.44 & - & - & - & - & - & - & - \\
\hline Duckeodendro cestroides & - & - & - & 0.46 & - & 0.46 & - & - \\
\hline Eschweilera atropetiolata & - & - & - & - & 15.9 & - & - & - \\
\hline Dipterix odorata & - & - & - & - & - & - & - & 4.92 \\
\hline Bellucia dichotoma & 5.88 & - & - & - & - & - & - & - \\
\hline Maquira esclerofila & 6.86 & 1.63 & - & 0.33 & - & - & 2.29 & 4.25 \\
\hline Osteophloeum platyspermum & - & - & - & - & - & - & - & 20 \\
\hline Micropholis williamii & 66.67 & - & - & - & - & - & - & - \\
\hline Siparuna guianensis & - & - & - & - & - & - & 3.57 & 1.79 \\
\hline Ampelocera edentula & 35.4 & 3.1 & 4.97 & 7.45 & - & - & - & 0.62 \\
\hline
\end{tabular}

${ }^{1} \mathrm{Da}=$ Doryctobracon areolatus $; \mathrm{O}=$ Opius sp.; Ua = Utetes anastrephae $; \mathrm{Aa}=$ Asobara anastrephae $; \mathrm{Pp}=$ Phaenocarpa pericarpa $; \mathrm{Id}=$ Idiasta delicata $;{ }^{2} \mathrm{An}=$ Aganaspis nordlanderi $;$ and Ap = Aganaspis pelleranoi .

\subsection{Tritrophic interactions}

Braconids and figitids parasitized insect host families larvae with practically the same frequencies (around $90 \%$ on tephritids and 7 and $8 \%$, respectively, on lonchaeids). This is the first record of parasitoids of Lonchaeidae frugivorous larvae in the Brazilian Amazon region.

The parasitoids developed in frugivorous larvae associated with eight species of fruit trees in nine plant families (Table 4). Braconids were attracted by representatives of seven plant families, demonstrating that this is a key group of frugivorous larvae parasitoids (Figure 2).

This is the first record of $D$. areolatus parasitism on Anastrepha spp. larvae on Guatteria discolor (Annonaceae), Ampelocera edentula (Ulmaceae), Maquira esclerofila (Moraceae), and Bellucia dichotoma (Melastomataceae) fruits. It is also the first record of D. areolatus on $M$. williamii (Sapotaceae) and A. edentula (Ulmaceae) fruits infested with two un- described Neosilba species. At RFAD, D. areolatus also parasitizes A. bahiensis larvae on Helycostylis tomentosa (Moraceae) and A. coronilli larvae on Bellucia grossularioides (Melastomataceae) (Tregue-Costa, 2004).

Among the species of Alysiinae, only Asobara anastrephae could be associated with Anastrepha bahiensis in fruits of Ampelocera edentula (Table 4). Phaenocarpa pericarpa was obtained from Neosilba spp. larvae in E. atropetiolata fruits (Lecythidaceae) (Table 4).

In this study, five new records of figitids were obtained in frugivorous larvae associated with five fruit species: Aganaspis nordlanderi in larvae of Anastrepha sp.4 in fruits of Siparuna guianensis (Siparunaceae); in larvae of Anastrepha sp.6 in fruits of M. esclerofila (Moraceae); and in larvae of Neosilba sp. 1 in fruits of Sapotaceae. According to Tregue-Costa (2004), at RFDA Aganaspis pelleranoi parasitizes larvae of Anastrepha sp. 6 in fruits of M. esclerofila (Moraceae). Aganaspis nordlanderi 
Table 4. Tritrophic relation between host fruits, frugivorous larvae, and their parasitoids at Adolpho Ducke Forest Reserve, Manaus, Amazonas, Brazil. January to July 2004.

\begin{tabular}{|c|c|c|c|c|c|}
\hline \multicolumn{2}{|c|}{ Host Fruits } & \multirow{2}{*}{$\begin{array}{c}\text { Frugivorous larvae } \\
\text { Tephritidae/ } \\
\text { Lonchaeaidae }\end{array}$} & \multirow[t]{2}{*}{$\mathbf{N}$} & \multirow{2}{*}{$\begin{array}{c}\text { Parasitoids } \\
\text { Braconidae/Figitidae }\end{array}$} & \multirow[t]{2}{*}{$\mathbf{N}$} \\
\hline Families & Species & & & & \\
\hline Annonaceae & Guatteria discolor & Anastrepha sp.* & 2 & Doryctobracon areolatus & 2 \\
\hline Lecythidaceae & Eschweilera atropetiolata & $\begin{array}{l}\text { Neosilba sp.5 and Neosilba } \\
\text { sp. } 1\end{array}$ & 2 & Phaenocarpa pericarpa & 1 \\
\hline Melastomataceae & Bellucia dichotoma & Anastrepha coronilli & 7 & Doryctobracon areolatus & 1 \\
\hline \multirow[t]{3}{*}{ Moraceae } & Maquira esclerofila & Anastrepha fractura & 32 & Aganaspis nordlanderi & 6 \\
\hline & & & - & Aganaspis pelleranoi & 3 \\
\hline & & & - & Doryctobracon areolatus & 8 \\
\hline \multirow[t]{2}{*}{ Sapotaceae } & - & Neosilba sp.1 & 1 & Aganaspis nordlanderi & 1 \\
\hline & Micropholis williamii & Neosilba sp.1 & 1 & Doryctobracon areolatus & 2 \\
\hline Siparunaceae & Siparuna guianensis & Anastrepha sp.4 & 2 & Aganaspis nordlanderi & 2 \\
\hline \multirow[t]{4}{*}{ Ulmaceae } & Ampelocera edentula & Anastrepha bahiensis & 12 & Asobara anastrephae & 5 \\
\hline & & & - & Utetes anastrephae & 2 \\
\hline & & & - & Doryctobracon areolatus & 17 \\
\hline & & & - & Asobara anastrephae & 2 \\
\hline \multirow[t]{5}{*}{ Ulmaceae } & Ampelocera edentula & $\begin{array}{l}\text { Anastrepha sp. } 7 \text { and } \\
\text { Anastrepha sp. } 8\end{array}$ & 2 & Doryctobracon areolatus & 1 \\
\hline & & Anastrepha bahiensis & 2 & Doryctobracon areolatus & 2 \\
\hline & & Anastrepha bahiensis & 4 & Doryctobracon areolatus & 3 \\
\hline & & Anastrrepha sp.* & 7 & Doryctobracon areolatus & 19 \\
\hline & & Neosilba sp.6 & 1 & Doryctobracon areolatus & 2 \\
\hline
\end{tabular}

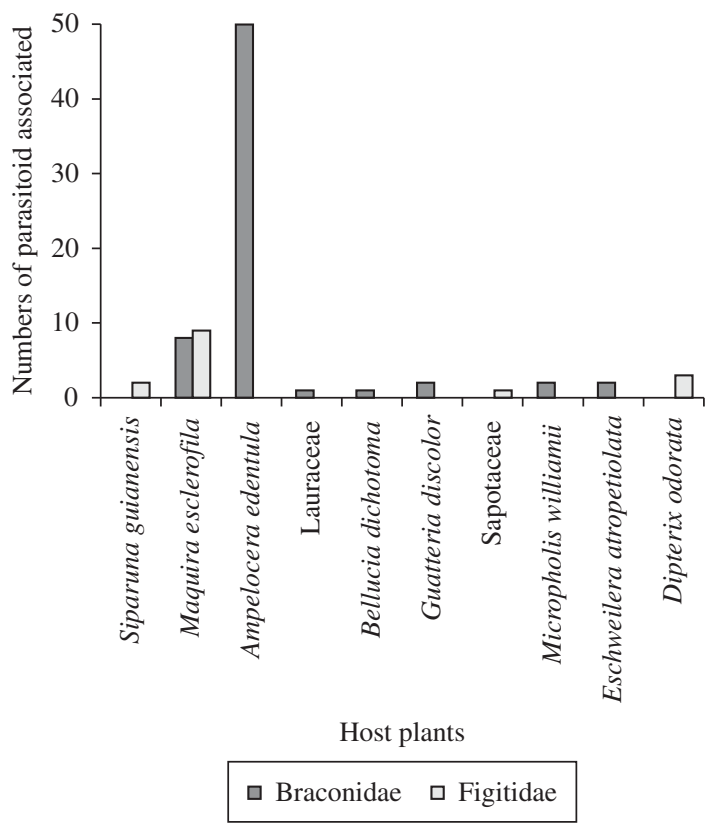

Figure 2. Number of parasitoids (Braconidae and Figitidae) on frugivorous larvae (Tephritoidea) associated with fruits at Adolpho Ducke Forest Reserve, Manaus, Amazonas, Brazil. January to July 2004. developed in larvae of Anastrepha coronilli in B. grossularioides fruits; Aganaspis pelleranoi developed in larvae of Anastrepha obliqua in Eugenia patrisii (Myrtaceae), and in larvae of Anastrepha atrigona in Pouteria durlandii (Sapotaceae) fruits (Table 4).

\section{Discussion}

From 17 species of Anastrepha parasitoids recorded in Brazil (Ovruski et al., 2000), seven species occur at RFAD, that is, approximately one half of the species already recorded in the country.

Collections in areas with undisturbed native vegetation like RFAD allowed the discovery of rather uncommon fruit fly parasitoids, such as Phaenocarpa pericarpa and Idiasta delicata. New associations among parasitoids, flies, and wild fruits could also be determined (Table 4).

Knowledge of these interactions are relevant for the management of economically important flies, since they can aid the conservation of native parasitoids. Wild fruits from the Amazon region are commonly used by the local population, and the production of some of them is under expansion. Such diversity of fruits also reflects on their great potential as hosts for frugivorous insects. Of the 176 species of fruits known in the Brazilian Amazon region, one half occurs in wild environments, which 
constitute natural fruit fly repositories, particularly for Anastrepha species (Silva, 1993).

The results obtained in this work demonstrate that D. areolatus parasitizes larvae in a range of wild hosts, and consequently has potential to maintain the balance of fruit fly populations in the reserve.

Aganaspis species also have a generalist behavior in the State of Amazonas, as previously observed in other states of Brazil (Guimarães et al., 2000). Probably, due to its behavior of penetrating the fruit (Ovruski, 1994; Guimarães et al., 2003), A. pelleranoi was more effective than the braconids in parasitizing larvae in Siparuna guianensis and Dipterix odorata fruits, which have a thick pulp, making it difficult for braconids to oviposit.

The combined effect of braconids and figitids on frugivorous insect populations may play an important role as natural enemies of fruit flies; however, the limited knowledge and scarcity of basic studies makes harder the use of these parasitoids in management programmes (Guimarães et al., 2000).

Fruit fly natural parasitism is quite variable and is affected by host fruit and host fly traits; its study is affected by collection location and timing (Canal-Daza and Zucchi, 2000). However, it is known that larvae living in relatively small fruits, with a thin pericarp and mesocarp, suffer relatively more parasitism (e.g. Hernándes-Ortiz et al., 1994). In this study, the highest parasitism percentages, as well as the greatest diversity of parasitoids were found in Maquira esclerofila and Ampelocera edentula fruits, which share these characteristics. In addition to fruit rind and pulp thickness, the length of the parasitoid ovipositor and size of the fly larva are factors that influence parasitism (Sivinski, 1991).

The larvae found in Micropholis williamii fruits showed a high parasitism percentage $(66.67 \%)$; however, only five puparia were obtained from this host. The occurrence of several parasitoid species in the same fruit affects their spatial and temporal distribution, due to interspecific competition (Sivinski et al., 1997).

Nine parasitoid species were found at RFAD, and all 15 tritrophic associations observed are new records for the Brazilian Amazon region. Therefore, this reserve is a reference locality and important natural reservoir of Amazonian frugivorous larva parasitoids.

Acknowledgements - To the Instituto Nacional de Pesquisas da Amazônia for project support. To Dr. José Albertino Rafael (Inpa) for support received during the study. To CNPq for financial resources from the Universal Project (Proceeding no.472978/2003-9). To CAPES for granting a Prodoc fellowship to the second author. Pedro Strikis for identification of Lonchaeidae.

\section{References}

ALUJA, M., RULL, J., SIVINSKI, J., NORRBOM, AL., WHARTON, RA., MACIAS-ORDÓNEZ, R., DIAS-FLEISCHER, F. and LÓPEZ, M., 2003. Fruit flies of the genus Anastrepha (Diptera: Tephritidae) and associated native parasitoids (Hymenoptera) in the Tropical Rainforest Biosphere
Reserve of Montes Azules, Chiapas, Mexico. Environmental Entomology, vol. 32, no. 6, p. 1377-1385.

ARAÚJO, VC., 1970. Fenologia de essências florestais amazônicas I. Manaus: INPA. Boletim do INPA. Pesquisas Florestais.

CANAL-DAZA, NA. and ZUCCHI, RA., 2000. Parasitóides: braconidae. In MALAVASI, A. and ZUCCHI, RA. (Eds.). Moscas das frutas de importância econômica no Brasil: conhecimento básico e aplicado. Ribeirão Preto: Holos Editora. p. $119-126$

CANAL-DAZA, NA., 1993. Espécies de parasitóides (Hymenoptera: Braconidae) de moscas-das-frutas (Diptera: Tephritidae) em quatro locais do Estado do Amazonas. Piracicaba: Universidade de São Paulo - USP/ ESALQ. 93p. Dissertação de Mestrado.

CREÃO, MIP., 2003. Espécies, distribuição e medidas de fauna de moscas-das-frutas (Diptera: Tephritidae) e seus parasitóides no Estado do Amapá. Manaus: Universidade Federal do Amazonas - UFAM; INPA. Dissertação de Mestrado.

FEARNSIDE, PM., 2003. A floresta amazônica nas mudanças globais. Manaus: INPA. 134p.

GUIMARÃES, JA., DIAS, NB. and ZUCCHI, RA., 2000. Parasitóides: Figitidae (Eucoilinae). In MALAVASI, A. and ZUCCHI, RA. (Eds.). Moscas das frutas de importância econômica no Brasil: conhecimento básico e aplicado. Ribeirão Preto: Holos Editora. p. 127-134.

GUIMARÃES, JA., GALLARDO, FE., DIAZ, NB. and ZUCCHI, RA., 2003. Eucoilinae species (Hymenoptera: Cynipoidea: Figitidae) parasitoids of fruit-infesting dipterous larvae in Brazil: identity, geographical distribution and host associations. Zootaxa, vol. 278, p. 1-23.

HERNÁNDEZ-ORTIZ V., PÉREZ-ALONSO, R. and WHARTON, RA., 1994. Native parasitoids associates with the genus Anastrepha (Diptera: Tephritidae) in los Tuxtlas Veracruz, Mexico. Entomophaga, vol. 39, no. 2, p. 171-178.

KRUESS, A. and TSCHARNTKE, T., 2000. Species richness and parasitism in a fragmented landscape: experiments and field studies with insects on Vicia sepium. Oecologia, vol. 122, no. 1, p. $129-137$.

LEONEL Jr., FL., ZUCCHI, RA. and CANAL-DAZA, NA., 1996. Parasitismo de moscas-das-frutas (Diptera: Tephritidae) por Braconidae (Hymenoptera) em duas localidades do Estado de São Paulo. Anais da Sociedade Entomológica do Brasil, vol. 25 , no. 2, p. 199-206.

MARQUES FILHO, AO., RIBEIRO, MNG., SANTOS, HM. and SANTOS, JM., 1981. Estudos climatológicos da Reserva Florestal Adolpho Ducke - Manaus - AM. IV Precipitação. Acta Amazônica, vol. 11, no. 4, p. 759-768

MATRANGOLO, WJR., NASCIMENTO, AS., CARVALHO, RS., MELO, ED. and JESUS, MARLI., 1998. Parasitóide de moscas-das-frutas (Diptera: Tephritidae) associados a frutíferas tropicais. Anais da Sociedade Entomológica do Brasil, vol. 27, no. 4 , p. 593-603.

MYERS, N., 1992. The primary source: tropical forest and our future. 2 ed. New York: W.W. Norton. 416p.

OVRUSKI, S., ALUJA, M., SIVINSKI, J. and WHARTON, R., 2000. Hymenoptera parasitoids on fruit-infesting Tephritidae (Diptera) in Latin America and Southern United States: 
diversity, distribution, taxonomic status and their use in fruit fly biological control. Integrated Pest Management Reviews, vol. 5, no. 2, p. 81-107.

OVRUSKI, SM., 1994. Comportamento en la deteccion del huesped de Aganaspis pelleranoi (Hym.: Eucoilinae) parasitóide de larvas de Ceratitis capitata (Diptera: Tephritidae). Revista de la Sociedad Entomológica Argentina, vol. 53, no. 1, p. 121-127.

RIBEIRO, JEL., HOPKINS, MJG., VICENTINI, A., SOTHERS, CA., COSTA, MAS., MARTINS, LHP., LOHMANN, LG., ASSUNÇÃO, PACL., PEREIRA, EC., SILVA, CF., MESQUITA, MR. and PROCÓPIO, LC., 1999. Flora da reserva Ducke: guia de identificação das plantas vasculares de uma floresta de terrafirme na Amazônia Central. Manaus: INPA.

RONCHI-TELES, B., 2000. Ocorrência e flutuação populacional de espécies de moscas-das-frutas e parasitóides, com ênfase para o gênero Anastrepha (Diptera: Tephritidae) na Amazônia Brasileira. Manaus: Universidade Federal do Amazonas - UFAM; INPA. 165p. Tese de Doutorado.

SILVA, NM. and RONCHI-TELES, B., 2000. Amapá, Amazonas, Pará, Rondônia e Roraima. In MALAVASI, A. and ZUCCHI, RA. (Eds.). Moscas-das-frutas de importância econômica no Brasil: conhecimentos básicos e aplicados. Ribeirão Preto: Holos Editora. p. 203-209.

SILVA, NM., 1993. Levantamento e análise faunística de moscas-das-frutas (Diptera: Tephritidae) em quatro locais do Estado do Amazonas. Piracicaba: Universidade de São Paulo USP/ ESALQ. 152p. Tese de Doutorado.

SILVA, NM., SILVEIRA NETO, S. and ZUCCHI, RA., 1996. The natural host plants of Anastrepha in the state of Amazonas,
Brasil. In STECK, GJ. and McPHERON, BA. (Eds.). Fruit fly pest: a world assessment of their biology and management. Delray Beach: St. Lucie Press. p. 353-357.

SIVINSKI, J., 1991. The influence of host fruit morphology on parasitization rates in the Caribbean fruit fly, Anastrepha suspense. Entomophaga, vol. 36, no. 3, p. 447-454.

SIVINSKI, J., ALUJA, M. and LOPES, M., 1997. Spatial and temporal distributions of parasitoids of Mexican Anastrepha species (Diptera: Tephritidae) within the canopies of fruit trees. Annals of the Entomological Society of America, vol. 90, no. 5, p. $604-618$

SIVINSKI, J., PIÑERO, J. and ALUJA, M., 2000. The distributions of parasitoids (Hymenoptera) of Anastrepha fruit flies (Diptera: Tephritidae) along an altitudinal gradient in Veracruz, Mexico. Biological Control, vol. 18, no. 3, p. $258-269$.

TREGUE-COSTA, AP., 2004. Biodiversidade de espécies de Anastrepha Schiner, 1868 (Diptera: Tephritidae) e seus parasitóides na Reserva Florestal Adolpho Ducke, Manaus, Amazonas, Brasil. Manaus: Universidade Federal do Amazonas - UFAM; INPA. 74p. Dissertação de Mestrado.

TROSTLE, M., CARREJO, NS., MERCADO, I. and WHARTON, RA., 1999. Two new species of Phaenocarpa Foerst (Hymenoptera: Alysiinae) from South America. Proceedings of the Entomological Society of Washington, vol. 101, no. 1, p. 197-207.

WHARTON, RA., MARSH, PM. and SHARKEY, MJ., 1997. Manual of the New World genera of the Braconidae (Hymenoptera). Washington: Special Publication of the International Society of Hymenopterists. 439 p. 